\title{
CARBON DIOXIDE, HYDROGRAPHIC, AND CHEMICAL DATA FROM THE F/S METEOR CRUISE NO. 18 IN THE NORTH ATLANTIC OCEAN (WOCE SECTION A1/E) DURING SEPTEMBER 1991
}

\author{
Contributed by \\ Kenneth M. Johnson ${ }^{1}$, B. Schneider ${ }^{2}$, L. Mintrop ${ }^{3}$, and D.W. R. Wallace' \\ 'Oceanographic and Atmospheric Sciences Division \\ Brookhaven National Laboratory \\ Upton, NY 11973 \\ ${ }^{2}$ Institut fuer Osteeforschung (IOW) \\ 18111 Rostock-Warnemunde \\ Germany \\ ${ }^{3}$ Institut fuer Meereskunde Kiel \\ Dusternbrooker Weg 20 \\ D-24105 Kiel 1 \\ Germany
}

Prepared for the

Carbon Dioxide Information Analysis Center

OAK RIDGE NATIONAL LABORATORY

Oak Ridge, Tennessee 37831-6335

managed by

MARTIN MARIETTA ENERGY SYSTEMS, INC.

for the

U.S. DEPARTMENT OF ENERGY

under contract DE-AC05-840R21400

This research was performed under the auspices of the United States Department of Energy under

Contract No. DE-AC02-76CH00016

\section{DISCLAIMER}

This report was prepared as an account of work sponsored by an agency of the United States Government. Neither the United States Government nor any agency thereof, nor any of their employees, makes any warranty, express or implied, or assumes any legal liability or responsibility for the accuracy, completeness, or usefulness of any information, apparatus, product, or process disclosed, or represents that its use would not infringe privately owned rights. Reference herein to any specific commercial product; process, or service by trade name, trademark, manufacturer, or otherwise does not necessarily constitute or imply its endorsement, recommendation, or favoring by the United States Government or any agency thereof. The views and opinions of authors expressed herein do not necessarily state or reflect those of the United States Government or any agency thereof. 


\section{ABSTRACT}

Johnson, K. M. ${ }^{1}$, B. Schneider ${ }^{2}$, L. Mintrop ${ }^{3}$, D.W. R. Wallace ${ }^{1}$. 1995. Carbon Dioxide, Hydrographic, and Chemical Data From the F/ S Meteor Cruise No. 18 in the North Atlantic Ocean (WOCE Section A1 / E) During September 1991.

Herein are given the procedures and methods used to obtain total carbon dioxide $\left(\mathrm{C}_{\mathrm{T}}\right)$, total alkalinity, and underway $\mathrm{pCO}_{2}$ data during the $\mathrm{F} / \mathrm{S}$ Meteor Cruise 18 in the North Atlantic Ocean (WOCE Section A1 / E). Instructions for accessing the data are provided.

The F/ S Meteor departed Reykjavik on September 2, 1991 and docked in Hamburg early on the moming of September 25, 1991 after 24 days at sea. A two day steam from Reykjavik brought the ship to the starting position for WOCE zonal section A1 / east (A1 / E) on September 5 . Section work began and ended with a closely spaced series hydrocasts on the SEGreenland $\left(60^{\circ} \mathrm{N} 42^{\circ} 30^{\prime} \mathrm{W}\right)$ and Porcupine Shelves $\left(52^{\circ} 20^{\circ} \mathrm{N} 14^{\circ} 15^{\prime} \mathrm{W}\right)$, respectively. The cast schedule was interrupted for equipment problems (6 and 7 September), current meter deployments $(9,10,11,14$, and 19 September), and by high seas (13,14, and 17 September). Of 64 CTD casts made, 58 were bottle casts including two calibration stations. Measurements made included CTD pressure, temperature, salinity, bottle salinity, oxygen, phosphate, nitrate, nitrite, silicate, total alkalinity, CFC's, total carbon dioxide, and continuous underway $\mathrm{PCO}_{2}$ of surface waters. Carbonate samples were collected from 31 section stations ( $55.4 \%$ of the section stations), one test station, and two calibration stations. Repeated XBT, and ADCP profiles were taken throughout the cruise.

The $\mathrm{C}_{\mathrm{T}}$ was measured using an automated sample processor (SOMMA) for extracting $\mathrm{CO}_{2}$ from seawater samples coupled to a Coulometer for detection of the extracted $\mathrm{CO}_{2}$. The precision and accuracy of the system was $\pm 1.60 \mu \mathrm{mol} / \mathrm{kg}$. Samples collected for total alkalinity were measured using standard potentiometric techniques; precision was $\pm 2.0 \mu \mathrm{mol} / \mathrm{kg}$. Underway $\mathrm{pCO}_{2}$ was measured by Infra Red (IR) Photometry; precision was $\pm 2 \mu \mathrm{atm}$. The work aboard the F / S Meteor was supported by the U. S. Department of Energy under contract DE-ACO2$76 \mathrm{CH} 00016$, and the Bundesministerium fuer Forschung und Technologie (BMFT) through grants 03F0545 A and MFG $099 / 1$.

1 Oceanographic and Atmospheric Sciences Division, Brookhaven National Laboratory, L.I., NY

2 Institut fuer Ostseeforschung (IOW), 18111 Rostock-Warnemünde, Germany

3 Institut fuer Meereskunde Kiel, Düsternbrooker Weg 20, D - 24105 Kiel 1, Germany 


\section{DISCLAIMER}

Portions of this document may be illegible in electronic image products. Images are produced from the best available original document. 


\section{BACKGROUND INFORMATION}

The World Ocean Circulation Experiment - World Hydrographic Program (WOCE - WHP) is a major component of the World Climate Research Program whose overall goal is to better understand the ocean's role in climate and climatic changes resulting from both natural and anthropogenic causes. Although total carbon dioxide $\left(\mathrm{C}_{\mathrm{T}}\right)$ is not an official WOCE measurement, a coordinated effort, supported in the USA by the Department of Energy (DOE), is being made on WOCE cruises through 1998 to measure the global spatial and temporal distributions of $\mathrm{C}_{\mathrm{T}}$ and other parameters in order to estimate the meridional transport of inorganic carbon in a manner analogous to the oceanic heat transport (Bryden and Hall, 1980; Brewer et al., 1989; Roemmich and Wunsch, 1985), and to build a data base suitable for carbon-cycle modeling and the subsequent estimation of anthropogenic $\mathrm{CO}_{2}$ increase in the oceans. The $\mathrm{CO}_{2}$ Survey is taking advantage of the sampling opportunities provided by the WOCE-WHP Cruises during this period. The final data set is expected to cover on the order of 23,000 stations.

This cruise, Meteor 18, from Reykjavik, Iceland to Hamburg, Germany from 2 - 25 September 1991 completed WOCE zonal Section A1/E. It was also one of a series of cruises starting in 1991 belonging to the North Atlantic Overturning Rate Determination (WOCE-NORD) program coordinated jointly between the Bundesamt fuer. Seeschiffahrt und Hydrographie, Hamburg and the Institut fuer Meereskunde, Hamburg involving seasonally repeated Hydrographic sections between southern Greenland and Iceland in combination with current measurements from moored arrays. Program objectives include the direct determination of the overturning rates and the intensity of the meridional transports of mass, heat, and salt. The A1/E section was chosen to be south of the major wintertime convection regions to avoid water mass formation processes while at the same time avoiding shallow topography which could cause difficulties in calculating volume transports.

This document describes the cooperative effort of chemical oceanographers from Brookhaven National Laboratory and the Institut fuer Meereskunde Kiel (IFMK) to make high quality $\mathrm{CO}_{2}$ measurements on WOCE Section A1/E during a 24 day expedition in the North Atlantic Ocean aboard the F/ S Meteor in September 1991. 


\section{DESCRIPTION OF THE EXPEDITION}

\subsection{R/V Meteor}

The Forschungs Schiff (F/S) Meteor is owned by the Federal Republic of Germany through the Ministry of Research and Technology (BMFT) who also financed its construction. It is operated by the German Research Foundation (DFG) who provide about $70 \%$ of its operating funds with the remainder coming from the BMFT. The DFG also plans the scientific cruises and appoints the Chief Scientists. The Operations Control Office of the University of Hamburg is responsible for the management, logistics, and the execution and supervision of ship operations. These functions are exercised through direct cooperation with expedition coordinators and through the managing owners, the Reedereigemeinschaft Forschungsschiffahrt (RF) GmbH, located in Bremen, Germany. The latter is responsible for hiring, provisioning, and coordinating ship maintenance. The Meteor is used for ocean research primarily in the Atlantic and Indian Oceans, and routinely carries scientists from many different countries. The Meteor was completed in 1986 in Travemunde, Germany:

$\begin{array}{ll}\text { Port of Registration } & \text { Hamburg } \\ \text { Call Sign } & \text { DBBH } \\ \text { Displacement } & 4780 \mathrm{t} \\ \text { Length } & 97.5 \mathrm{~m} \\ \text { Beam } & 16.5 \mathrm{~m} \\ \text { Draught (maximum) } & 5.6 \mathrm{~m} \\ \text { Speed } & 12 \mathrm{kn} \\ \text { Depth Main Deck } & 7.7 \mathrm{~m} \\ \text { Personnel } & \text { Crew: 32; Scientists: } 30 \\ \text { Main Engine } & 4 \times \text { Mak6M 322 =4 x 1000 kW at } 750 \mathrm{rpm} \\ \text { Maximum Cruise Duration } & 60 \text { days } \\ \text { Science Quarters } & 20 \text { laboratories on main deck (approx. } 400 \mathrm{~m}^{2} \text { ) }\end{array}$


$2.2 \mathrm{R} / \mathrm{V}$ Meteor Cruise No. 18 Information

Ship Name

Cruise / Leg

Location

Dates

Funding

Chief Scientist

Master
Meteor

Cruise No. 18

Reykjavik, Iceland to Hamburg, Germany

September 2 - September 25, 1991

Deutsche Forschungs Gemeinshaft (DFG)

U. S. Department of Energy (DOE)

Professor Dr. Jens Meincke

Heinrich Bruns

Parameters measured, institution, and responsible Investigators

Parameter

CTD, Salinity, XBT

Nutrients

Oxygen

CFM's

Tritium, $\mathrm{He},{ }^{14} \mathrm{C}$

$\mathbf{C}_{\mathrm{T}}$

$\mathrm{pCO}_{2}$

Alkalinity

ADCP

Rain Gauges
Institution
PI

Participating Institutions

BSH

SIO-ODF

SIO-ODF

UBP

IUPH

BNL, IFMK

IFMK

IFMK

IFMH

IFMK
A. Sy

J. Swift, D. Bos, D. Muus

J. Swift, D. Bos, D. Muus

W. Roether, A. Putzka

R. Bayer

K. Johnson, B. Schneider,

A. Morak, R. Ramirez

B. Schneider

L. Mintrop, A. Korves

M. Bersch, J. Meincke

H.-J. Isemer

BNL

Brookhaven National Laboratory

BSH

Bundesamt für Seeschiffahrt und Hydrographie

IFMH

Institut fuer Meereskunde der Universităt Hamburg

IFMK

Institut fuer Meereskunde der Universität Kiel

IUP

Institut für Umweltphysik der Universität Heidelberg

SIO-ODF

Scripps Institution of Oceanography - Ocean Data Facility

UBP

Universität Bremen, Fachbereich Physik

OSU

Oregon State University 


\subsection{Brief Cruise Summary}

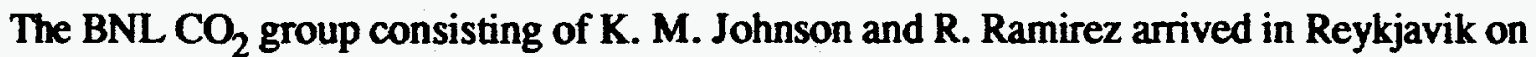
August 29, and went aboard the next day to join the Kiel $\mathrm{CO}_{2}$ group under the direction of Drs. Bernd Schneider, and Lutger Mintrop. Dr. Jens Meincke was already aboard as Chief Scientist. Setting up of the equipment began on the 30th, and was completed on the morning of September 2. The F / S Meteor departed Reykjavik at 11 am on September 2, 1991 under captain Heinrich Bruns. We immediately encountered rough weather conditions with gale force winds of Beaufort 8 - 9. Two test stations were taken during the transit across the Denmark Straight to the first WOCE station (no. 558) on the SE-Greenland shelf on September 5 . The earlier gale force winds were replaced by a quiet period characterized by humid air masses over cold water resulting in fog. The hydrocast routine was interrupted by winch and / or rosette bottle release problems on September 6 and 7, and current meter deployments on September 9, $10,11,14$, and 19 September. Bad weather forced several delays when a low passed just north of the Meteor to drop the pressure to $980 \mathrm{hPa}$ causing a work pause on September 13 when winds gusted up to 11 Beaufort and the seas rose to $8 \mathrm{~m}$. This scenario was repeated on September 17, and the slowly receding sea states thereafter, continued to plague the oceanographic work until the end of the Hydrographic program with station 622 on September 21 . Each especially rough period was followed by reduced sampling stations ( 12 instead of 24 bottles on each rosette), but these stations were restricted to short lines perpendicular to the WOCE line. The station locations are shown in Figure 1. Only station 607 of the 6 stations $(592,593,595,606,607$, and 608) taken normal to the WOCE line was sampled for carbonate system parameters. XBT measurements were made at selected CTD stations in parallel with the CTD casts, and acoustic Doppler current profiles (ADCP) to measure the instantaneous near surface currents were made continuously from September 2 to September 22. The distribution of the recording current meter moorings (A-F) to measure the long-term currents along the Al / E section is shown in Figure 2.

There were two Single-Operator Multiparameter Metabolic Analyzers (SOMMA) from BNL (hereafter BNL I and BNL II) on board for this cruise, one potentiometric alkalinity titrator from IFMK, and an IR-based system for underway $\mathrm{PCO}_{2}$ belonging to IFMK. Not counting duplicates, 583 total carbonate samples, normally in conjunction with tracer samples, were taken from 31 section stations, one test station (557) and two calibration stations $(581,608)$ out of a total of 58 bottle casts. All 58 stations could not be sampled for tracers and $\mathrm{C}_{\mathrm{T}}$ because of the time required for analysis. The standard WOCE parameters (oxygen, nutrients, and salinity) were sampled on all stations, and on approximately every other station these were augmented by the tracer samples for CFC, carbonate, helium, tritium, and radiocarbon as the ship steamed eastward from the 
southeastem tip of Greenland to the Irish Coast. Thus the density of the $\mathrm{CO}_{2}$ sampling was fairly constant at approximately 2 stations per day, while the underway $\mathrm{pCO}_{2}$ system operated continuously.

Both electrical and mechanical problems were noted for each of the SOMMA-Coulometer Systems. BNL II was most severely affected. It was declared nonoperational on September 16 when the magnetic valves on the SOMMA chassis could no longer be operated reliably, the electronic calibration factor suddenly changed by $+0.11 \%$ (a factor of 10 higher than the usual precision of $\pm 0.01 \%$ ), and the communication between the keyboard and $\mathrm{PC}$ became erratic. The final Certified Reference Material (CRM) run on this date was $6 \mu$ mols $/ \mathrm{kg}$ lower than the certified value, and test sample duplication was equally poor. When this system was operated several months later in the laboratory all components functioned satisfactorily so we were unable to determine the cause of the shipboard difficulties. BNL I experienced two serious problems. The BNL I Coulometer was lost when the photodetector amplifier failed on September 7. Fortunately, a back-up Coulometer from Kiel was available, and it was immediately placed in service.

Secondly, the gas calibration system apparently failed on September 10 due to cross-talk between the the gas sample loops $\left(\mathrm{CO}_{2}\right.$ leaking from one loop into the other via a surface scratch or scoring of the valve which contaminated the carrier gas). This manifested itself as a very noisy system with a very high and unusable blank. It was corrected by disconnecting the gas sample valve from the system so that the carrier gas $\left(\mathrm{N}_{2}\right)$ passed directly from the gas cylinder into the SOMMA stripper.

Due to the rough weather, plans for a return voyage around the north of Scotland to Hamburg were changed, and the ship arrived in Hamburg on September 25, via the English Channel where winds astern arising from a low pressure near the Faeroe Islands hastened the return voyage. 


\section{DESCRIPTION OF METHODS}

Water samples were collected in 24 General Oceanics 101 -Niskin bottles mounted on a Neil Brown Mark III instrument (S/N NB3) provided by the Institut fuer Meereskunde Kiel (IFMK). Data was acquired at a rate of $32 \mathrm{~ms} /$ cycle using Oceansoft rev. 3.1 (EG \& G). Further details are given by Meincke (1993), and additional data concerning post and precruise laboratory calibrations of the CTD temperature, pressure, conductivity, and oxygen sensors may be found in Siedler and Zenk (1992), and the WHP One-Time Section A9 Data Report (1994). ADCP measurements to a depth of $300 \mathrm{~m}$ were made nearly continuously (some breaks for rough weather and minor computer malfunctions) from September 2 - 22 with a hull-mounted system from RD Instruments (San Diego) using a pulse frequency of $150 \mathrm{KHz}$.

The rosette systems used with the CTD on this cruise were subject to various mechanical / electrical problems such that tripping failures were not uncommon--especially at stations $596-613$.

Repeated checks on board and several careful verifications using the complete bottle data sets have been carried out, and the current pressures for each sample are considered correct by the responsible personnel. Reversing thermometers of both the electronic (SIS, Kiel) and mechanical (Gohla Precision, Kiel) types were also read at the completion of each cast. In so far as possible, the processing and quality control of CTD and bottle data done at BSH followed the published guidelines in the WOCE Operations Manual (WHPO 91-1, 1991). Salinity corrections were made using bottle salinities measured $1-2$ days after collection and determined on a Guildine Autosal model 8400A standardized at each station with IAPSO water (batch P112). Due to temporal conductivity sensor shifts, the corrections were made for station nos. 558 - 566, 567 602 , and $603-622$ separately. The final salinity data is expected to be accurate to \pm 0.002 PSU. Oxygen sensor data correction was carried out according to the guidelines given by Millard (1991). Bottle oxy gen was determined by Winkler titration after the technique of Carpenter (1965) with the modifications of Culberson et al. (1991) using standards and blanks run in seawater. Subsequently, all Winkler results were recalculated and verified by ODF in La Jolla. The concentrations of nitrate, nitrite, phosphate, and silicate dissolved in seawater were determined on samples collected in high density polyethylene screwcapped bottles using a Technicon Autoanalyzer according to procedures given in Hager et al. (1972) and Atlas et al. (1971), using the spectrophotometric methods of Armstrong et al. (1967) and Bernhardt and Wilhelms (1967). The analyses were completed within 24 hours of sampling including storage at $6^{\circ} \mathrm{C}$ for no more than 15 hours. Preweighed standards were used to prepare the working standard on board ship.

The total carbon dioxide concentration $\left(\mathrm{C}_{\mathrm{T}}\right)$ was determined using an automated 
coulometric system (SOMMA) described and designed by K. M. Johnson and co-workers (Johnson et al., 1985; Johnson et al., 1987, Johnson and Wallace, 1992). Some 583 individual samples along with 158 duplicates (total analyzed $=741$ ) from 33 stations were collected in 300 $\mathrm{mL}$ precombusted $\left(450^{\circ} \mathrm{C}\right.$ for $24 \mathrm{~h}$ ) BOD bottles and immediately poisoned with $\mathrm{HgCl}_{2}$ according to the DOE Handbook of Methods (DOE, 1994). Before analysis, they were kept in darkness in a cold room until thermally equilibrated to the analytical temperature. Some 61 Certified Reference Materials (CRM) supplied by Dr. Andrew Dickson of the Scripps Institution of Oceanography (see DOE Handbook of Methods, 1994) were also analyzed (37 on BNL I and 24 on BNL II). The CRM were from Batch 7 which was a filtered sterile salt solution $(S=37.12)$ spiked with $\mathrm{Na}_{2} \mathrm{CO}_{3}$ analyzed for $\mathrm{C}_{\mathrm{T}}$ by vacuum - extraction / Manometry in the laboratory of C. D. Keeling at SIO. The certified $C_{T}$ value was $1926.39 \pm 0.91 \mu \mathrm{mol} / \mathrm{kg}(\mathrm{n}=13)$.

Seawater introduced from an automated To Deliver (TD) pipette into a stripping chamber was acidified and the resultant $\mathrm{CO}_{2}$, after drying, was coulometrically titrated on a model 5011 UIC Coulometer. In the coulometer cell, the acid (hydroxyethylcarbamic acid) formed from the reaction of $\mathrm{CO}_{2}$ and ethanolamine was titrated coulometrically (electrolytic generation of $\mathrm{OH}^{-}$) with photometric endpoint detection. The product of the current passed through the cell during the titration and time was related by Faraday's Constant to the number of moles of $\mathrm{OH}$ generated and thus to the moles of $\mathrm{CO}_{2}$ which reacted with ethanolamine to form the acid. The SOMMACoulometer System was calibrated with pure $\mathrm{CO}_{2}$ using hardware consisting of an 8 port Gas Sampling Valve (GSV) with two sample loops connected to a source of pure $\mathrm{CO}_{2}$ through an isolation valve with the vent side of the GSV plumbed to a barometer. When a gas loop was filled with $\mathrm{CO}_{2}$, the mass (moles) of $\mathrm{CO}_{2}$ contained therein was calculated by multiplying the loop volume $(V)$ by the density of $\mathrm{CO}_{2}$ at the ambient $\mathrm{T}$ and $\mathrm{P}$. Density was calculated from the molar volume of $\mathrm{CO}_{2}\left(\mathrm{~V}\left(\mathrm{CO}_{2}\right)\right)$ obtained iteratively from an equation of state using the instantaneous barometric pressure $(P)$, loop temperature $(T)$, and the first virial coefficient $\mathrm{B}(T)$ for pure $\mathrm{CO}_{2}$ :

$$
\mathrm{V}\left(\mathrm{CO}_{2}\right)=\mathrm{RT} / \mathrm{P}\left(1+\mathrm{B}(\mathrm{T}) / \mathrm{V}\left(\mathrm{CO}_{2}\right)\right)
$$

The ratio of the calculated mass to that determined coulometrically, was the gas calibration factor (CALFAC) used to correct the subsequent titrations for small departures from $100 \%$ theoretical (see DOE Handbook of Methods, 1994). The volume of the loops was determined gravimetrically with deionized water by the method of Wilke et al. (1993). The standard operating procedure was to make gas calibrations daily, or for each new titration cell used (normally, one cell per day). 
The " to deliver " volume (TDV) of the SOMMA sample pipette was determined before the cruise gravimetrically with milli-Q deionized water which had been degassed with Helium. The thermostatted sample pipette was filled with water at the same temperature, and then discharged into preweighed $50 \mathrm{~mL}$ serum bottles which were reweighed on a model R300S (Sartorius, Göttingen, Germany) balance. The apparent weight ( $g$ ) of water collected $\left(\mathrm{W}_{\mathrm{air}}\right)$ was corrected to the mass in vacuo $\left(\mathrm{M}_{\mathrm{vac}}\right)$ from:

$$
\mathrm{M}_{\mathrm{vac}}=\mathrm{W}_{\mathrm{air}}+\mathrm{W}_{\mathrm{air}}(.0012 / d-.0012 / 8.0)
$$

where .0012 is the sea level density of air at $1 \mathrm{~atm}, d$ is the density of the calibration fluid at the pipette temperature and sample salinity, and 8.0 is the density of the stainless steel weights. The to deliver volume (TDV) was:

$$
\mathrm{TDV}=\mathrm{M}_{\mathrm{vac}} / d
$$

This procedure was repeated at sea except the serum bottles were crimp-sealed and reweighed on shore within three weeks of collection. The precruise calibrated " to deliver "volume of the pipette for system BNL I was $28.7108 \mathrm{~mL}$ at $20^{\circ} \mathrm{C}$. During the cruise the pipette temperature was kept at approximately $10.2 \pm 0.3^{\circ} \mathrm{C}$. The calculated TDV at $10.2^{\circ} \mathrm{C}\left(\mathrm{TDV}_{\mathrm{T} 2}\right)$ was $28.7080 \mathrm{~mL}$ from:

$$
\operatorname{TDV}_{\mathrm{T} 2}=\operatorname{TDV}_{\mathrm{T} 1}\left[1+\mathrm{a}_{\mathrm{v}}\left(\mathrm{T}_{2}-\mathrm{T}_{1}\right)\right]
$$

where $\mathrm{a}_{\mathrm{v}}$ is the coefficient of volumetric expansion for pyrex-type glass $\left(1 \times 10^{-5}{ }^{\circ} \mathrm{C}^{-1}\right), \mathrm{T}_{2}$ the measurement temperature, and $T_{1}$ the calibration temperature. The corresponding results for the BNL II pipette were 29.6954 and $29.6925 \mathrm{~mL}$, respectively. During the cruise $8 \mathrm{TDV}$ samples were collected at $10.2^{\circ} \mathrm{C}$ from the BNL I pipette and sealed for reweighing. The TDV from these weighings was $28.6845 \pm 0.0058 \mathrm{~mL}(0.02 \%)$ which differed from the calculated TDV of $28.7080 \mathrm{~mL}$ by $-0.0235 \mathrm{~mL}$ or $-0.082 \%$. For the BNL Il pipette 11 samples were taken at 10.2 ${ }^{\circ} \mathrm{C}$ which gave a TDV of he $29.6712 \pm 0.0065 \mathrm{~mL}(0.02 \%)$ which differed from the calculated TDV of $29.6925 \mathrm{~mL}$ by $-0.0213 \mathrm{~mL}$ or $-0.072 \%$. Because the original laboratory calibration took place at $20^{\circ} \mathrm{C}$, while all of the analytical work aboard ship was done at $10.2 \pm 0.3$ we have used the latter (shipboard) results for TDV to calculate the $\mathrm{C}_{\mathrm{T}}$ values (i.e., for BNL I, TDV = $28.6845 \mathrm{~mL}$; for BNL II, TDV $=29.6712 \mathrm{~mL}$ ). Interestingly, the data confirmed our current practice of ensuring identical calibration and analytical temperatures because it appeared that just correcting for glass expansion was not adequate to describe the TDV at temperatures significantly different from the calibration temperature (see also DOE (1994)). 
An IBM compatible computer with two RS232 serial, a 24 line Digital Input / Output ( I / O), and Analog to Digital (A / D) ports was used to control the coulometer, barometer, solid state control relays, and temperature sensors, respectively. The temperature sensors (model LM34CH, National Semiconductor, Santa Clara, $\mathrm{CA}$ ) with a voltage output of $10 \mathrm{mV} /{ }^{\circ} \mathrm{F}$ built into the SOMMA were calibrated against thermistors certified to $0.01{ }^{\circ} \mathrm{C}$ (PN CSP60BT103M, Thermometrics, Edison, NJ) using a certified mercury thermometer as a secondary standard. These sensors monitored the pipette, gas sample loop, and the coulometer cell temperatures. The barometer, model 216B-101 Digiquartz Transducer (Paroscientific, Inc. Redmond, WA) was factory-calibrated for pressures between 11.5 and 16.0 psia. The SOMMA software was written in GWBASIC Version 3.20 (Microsoft Corp., Redmond, WA), and the instrument was driven from an options menu appearing on the PC monitor.

The analytical method for $\mathrm{C}_{\mathrm{T}}$ used for Cruise No. 18 differed from the technique described in an earlier data report (Johnson et al., 1995) for Meteor Cruise No. 15 (March 1991) in that an electronic calibration procedure was used to check the theoretical response of the coulometers's voltage to frequency converter (VFC) as described in Johnson et al. (1993) and DOE (1994). Briefly, at least two levels of current (usually 50 and $2 \mathrm{~mA}$ ) were passed through an independent and very precisely known resistance (R) for a known time. The voltage $(V)$ across the resistance was continuously measured and the instantaneous current (I) across the resistance was calculated from Ohm's law and integrated over the calibration time. Then the number of pulses (counts) accumulated by the VFC during this time was compared to the theoretical number computed from the factory-calibration of the VFC (frequency $=10^{5}$ pulses (counts) generated $/ \mathrm{sec}$ at $200 \mathrm{~mA}$ ) and the measured current. If the VFC was perfectly calibrated, electronic calibration yielded a straight line passing through the origin (intercept $=0$ ) with a slope of 1 . Calibrations and titrations were done with the coulometer in the counts mode (the total charge passed during a titration was displayed as the number of counts accumulated by theVFC). From the factory-calibration of the VFC, and the value of the Faraday ( 96489 Coulomb / mol) a scaling factor of $4.82445 \times 10^{3}$ counts / $\mu$ mol was derived, and the theoretical number micromoles of Carbon titrated (m) was:

$$
\mathrm{m}=\left[\text { Counts } / 4824.45-\left(\text { Blank } * \mathrm{~T}_{\mathrm{T}}\right)-\left(\text { ECint }{ }^{*} \mathrm{I}_{\mathrm{T}}\right)\right] / \text { ECslope }
$$

where $T_{T}$ was the length of the titration in minutes, Blank the system blank in $\mu \mathrm{mol} / \mathrm{min}$, ECint was the intercept from electronic calibration in $\mu \mathrm{mol} / \mathrm{min}, \mathrm{l}_{\mathrm{T}}$ the time of continuous current flow in min, and ECslope was the slope from electronic calibration. Note that the slope obtained from the electronic calibration procedure applied for the entire length of the titration, but the intercept 
applied only for the period of continuous current flow (usually 3 - $4 \mathrm{~min}$ ). The sample total carbon dioxide concentration $\left(\mathrm{C}_{\mathrm{T}}\right)$ in $\mu \mathrm{mol} / \mathrm{kg}$ was calculated from:

$$
\mathrm{C}_{\mathrm{T}}=\left[\mathrm{m} *(\mathrm{CALFAC}) *\left(1000 / \mathrm{TDV}_{\mathrm{T}}^{*} p\right)\right] * 1.00017
$$

where CALFAC is the gas calibration factor, $\mathrm{TDV}_{\mathrm{T}}$ is the " to deliver " volume of the pipette in $\mathrm{mL}$ at the analytical temperature, $p$ is the density of sea water in $\mathrm{kg} / \mathrm{L}$ from the equation of state (Millero and Poisson, 1981), and 1.00017 corrects for the dilution of the sample by the $100 \mu \mathrm{L}$ of $\mathrm{HgCl}_{2}$ solution added to the sample bottle.

As a consequence of the coulometer and gas calibration problems described in section 2.3, BNL I was operated after September 12 without a functioning gas calibration system. For sample $\mathrm{C}_{\mathrm{T}}$ calculations after September 12, the mean calibration factor (CALFAC) of $1.002844(n=7)$ obtained for the period 4 thru 10 September was used between September 13 and September 23. No samples were run on BNL I on September 11 and 12. System BNL II was continuously operated between September 4 and 15 and calculations were made using the daily gas calibration factors for that instrument. No samples were run on system BNL II after 15 September. The results of the CRM analyses are shown in Table 1.

Table 1. Accuracy: Summary of CRM $\mathrm{C}_{\mathrm{T}}$ analyses made aboard the F/ $\mathrm{S}$ Meteor during Cruise no. 18 in September 1991 with two SOMMA-Coulometer Systems (BNL I and BNL II). The CRM were from batch 7 and had a salinity of 37.12 and a $C_{\mathrm{T}}$ of $1926.39 \pm 0.91 \mu \mathrm{mol} / \mathrm{kg}$ $(n=13)$.

\begin{tabular}{lcccccc}
\hline System & $\begin{array}{c}\text { No. } \\
\text { (n) }\end{array}$ & $\begin{array}{c}\text { Mean } \\
\mu \mathrm{mol}\end{array}$ & $\begin{array}{c}\text { S. D. } \\
\text { kg }\end{array}$ & $\begin{array}{c}\text { R. S. D. } \\
\%\end{array}$ & $\begin{array}{c}\text { Difference } \\
\text { found - CRM }\end{array}$ & Period \\
\hline BNL I ${ }^{\mathrm{a}}$ & 14 & 1926.19 & 0.89 & 0.05 & -0.20 & $4-10$ September \\
BNL I $^{\mathrm{b}}$ & 23 & 1925.66 & 1.46 & 0.08 & -0.73 & $13-23$ September \\
BNL II & 24 & 1926.90 & 1.65 & 0.09 & +0.51 & $4-15$ September \\
Combined & 61 & 1926.27 & 1.52 & 0.08 & -0.12 & $4-23$ September
\end{tabular}

a Period with functioning gas calibration unit (September 4 - 10).

b Period without a functioning gas calibration unit (September 13 - 22). 
This was the first cruise where two complete SOMMA systems were employed side-by-side to analyze samples from the same profile, and in addition to the CRM analyses, measurements of system precision and bias were made. The system precision data are given in Table 2. For these data, "within-sample" precision was the average difference between two replicates analyzed from the same BOD bottle, "between-sample" precision was the average difference between duplicate samples taken from a single Niskin Bottle, "between-Niskin" precision was the average difference between single bottles taken from two Niskin Bottles closed at the same depth, and $\mathrm{Sp}^{2}$ was the pooled standard deviation from the combined analyses of samples filled from multiple Niskin Bottles closed at the same depth (stations 557, 581, and 608) and analyzed over a period of several days. The $\mathrm{Sp}^{2}$ was the square root of the the pooled variance according to Youden (1951):

$$
s_{p}^{2}=\frac{\sum_{i=1}^{K}\left(\sum_{j=1}^{n_{i}}\left(x_{i j}-\bar{x}_{j}\right)^{2}\left[\left(\sum_{j=1}^{n_{i}}\left(x_{i j}-\bar{x}_{j}\right)^{2} / n_{i}\right]\right)\right.}{\sum_{i=1}^{K} n_{i}-K}
$$


Table 2. Precision: Summary of sample precision for $\mathrm{C}_{\mathrm{T}}$ analyses made aboard the $\mathrm{F} / \mathrm{S}$ Meteor during Cruise no. 18 in September 1991 with two SOMMA-Coulometer Systems (BNL I and $\mathrm{BNL}$ II). Precision data, except for $\mathrm{Sp}^{2}$, are given as the absolute value of the average differences $\mathrm{a}$ between duplicates. The number of comparisons ( $\mathrm{n}$ ) are shown in parentheses, while for $\mathrm{Sp}^{2}, \mathrm{k}$ is the number of test sample station data sets from each instrument and $n$ is the combined number of samples analyzed by both instruments.

\begin{tabular}{lcclc}
\hline System & \multicolumn{3}{c}{ Bottle Precision $( \pm \mu \mathrm{mol} / \mathrm{kg})$} & $\mathrm{Sp}^{2}$ \\
& within-sample (n) & between-sample (n) & between-Niskin $(\mathrm{n})$ & $(\mathrm{k}, \mathrm{n})$ \\
\hline & & & & \\
BNL I & $0.77(18)$ & $0.73(31)$ & $0.39(12)$ & $1.49(3,26)$ \\
BNL II & $1.10(19)$ & $0.83(3)$ & $0.65(3)$ & $1.68(2,26)$ \\
Totals & $0.93(37)$ & $0.79(34)$ & $0.52(15)$ & $1.59(5,52)$ \\
\hline
\end{tabular}

n

a $\sum$ abs $\left(x_{1}-x_{2}\right) / n$ where $n$ is the number of comparisons between duplicates $x_{1}$ and $x_{2}$. $\mathrm{x}=1$

The combined precision $\left(\mathrm{Sp}^{2}\right)$ for the $\mathrm{A} 1 / \mathrm{E}$ samples was $\pm 1.59 \mu \mathrm{mol} / \mathrm{kg}$ which agreed very well with the precision of the CRM analyses $( \pm 1.52 \mu \mathrm{mol} / \mathrm{kg}, \mathrm{n}=61$, Table 1$)$. Note that BNL I, as a rule, gave slightly better precision than BNL II, and that the other precision estimates were consistently better than $\mathrm{Sp}^{2}$, however, the higher figure of $\pm 1.59 \mu \mathrm{mol} / \mathrm{kg}$ was considered to be the appropriate estimate of overall analytical precision because it included all sources of error-instrumental, calibration, and sampling-encountered over a period of several days.

System bias was checked by analyzing the calibration station (581) samples from a depth of approximately $2033 \mathrm{~m}$ on both instruments over several days. For BNL I the mean result was $2159.07 \pm 0.61 \mu \mathrm{mol} / \mathrm{kg}(\mathrm{n}=5$, analyzed between September 12 and 16), and the corresponding result for BNL II was $2158.26 \pm 1.18(n=12$, analyzed between September 11 and 13$)$. The absolute value of the difference was $0.81 \mu \mathrm{mol} / \mathrm{kg}$ with BNL I giving a slightly higher result. In addition, duplicate bottles from 33 samples were analyzed on each instrument during the period 4 to 15 September. The bias data are summarized in Table 3. 
Table 3. Bias: Summary of sample $\mathrm{C}_{\mathrm{T}}$ analyses for duplicate samples where one of the duplicates was analyzed on SOMMA-Coulometer System BNL 1, and the other was analyzed on System BNL II aboard the F / S Meteor during Cruise No. 18. Only the analyses made between September 4 - 15, 1991, when both instruments were operational are included in this table.

\begin{tabular}{|c|c|c|}
\hline Comparison & BNL I (n) & BNL $\Pi(n)$ \\
\hline
\end{tabular}

$\begin{array}{lllll}\text { CRM } & 1926.32(19) & 1926.90(24) & -0.58 & 0.58 \\ \text { Station 581 } & 2159.07(5) & 2158.26(12) & +0.81 & 0.81 \\ \text { All Stations } & 2125.75(33) & 2127.48(33) & -1.73 & \underline{-0.80} \\ \text { Means } & & & -0.50 & 1.09\end{array}$

In aggregate, Tables 1 - 3 indicated that while System BNL I tended to give slightly lower results, any instrumental bias was within the overall precision found for the entire data set ( $\pm 1.59 \mu \mathrm{mol} / \mathrm{kg}$, Table 2), and accordingly no correction of any kind for instrumental bias has been applied to the data.

As a final estimate of data quality, duplicate samples from 7 Niskin bottles at five stations were collected for later shore-based reference analyses of $\mathrm{C}_{\mathrm{T}}$ in the laboratory of $\mathrm{Dr}$. Charles Keeling at SIO by vacuum extraction / Manometry. The results are given in Table 4 where the BNL, data are compared to the SIO results (Guenther et al., 1994). Temperature sensors were not included in the shipping crates, as is now standard operating procedure, so the temperature history of these samples was not known between cold storage aboard ship and their arrival at SIO. 
Table 4. Comparison of shipboard analyses of $\mathrm{C}_{\mathrm{T}}$ by Coulometry (BNL) during the $\mathrm{M} 18$ Cruise, and the shore-based reference analyses of $\mathrm{C}_{\mathrm{T}}$ by Manometry on duplicate samples in the laboratory of C. D. Keeling at the Scripps Institution of Oceanography (SIO). The reference analyses were made in February - March 1994. This table supersedes Tables 3e and 5e of Guenther et al. (1994). Abbreviations: sample, Spl; salinity, $\mathbf{S}$.

\begin{tabular}{lccccccc}
\hline Station & Spl Date & Niskin & $\begin{array}{c}\text { Depth } \\
(\mathrm{m})\end{array}$ & $\begin{array}{c}\mathrm{C}_{\mathrm{T}}(\mathrm{BNL}) \\
\mu \mathrm{mol} / \mathrm{kg}\end{array}$ & $\begin{array}{c}\mathrm{C}_{\mathrm{T}}(\mathrm{SIO}) \\
\mu \mathrm{mol} / \mathrm{kg}\end{array}$ & $\begin{array}{c}\text { Diff. } \\
\mathrm{BNL}-\mathrm{SIO}\end{array}$ & $\mathrm{S} \mathrm{Diff.}^{\mathrm{a}}$ \\
\hline $\mathbf{5 7 5}$ & 09.09 .91 & 24 & 10 & 2088.25 & 2087.98 & +0.27 & +0.002 \\
575 & 09.09 .91 & 13 & 1095 & 2152.24 & 2154.55 & -2.31 & -0.019 \\
580 & 10.09 .91 & 23 & 27 & 2085.75 & 2094.58 & -8.83 & -0.003 \\
580 & 10.09 .91 & 1 & 2367 & 2157.52 & 2160.00 & -2.48 & -0.003 \\
$581^{\mathrm{b}}$ & 10.09 .91 & 2 & 2033 & 2158.48 & 2158.73 & -0.25 & -0.004 \\
596 & 14.09 .91 & 14 & 690 & 2167.83 & 2167.74 & +0.09 & -0.005 \\
603 & 16.09 .91 & 1 & 4063 & 2202.42 & 2203.84 & -1.42 & -0.001 \\
means & & & & & & -2.13 & -0.005 \\
\hline
\end{tabular}

a The difference between the ship's CTD sample salinity and the salinity measured at SIO.

b The calibration station. The BNL result is the mean of 17 analyses on the two systems between 11 and 16 September.

Note that our final $\mathrm{C}_{\mathrm{T}}$ data (Table 4) differ from the preliminary $\mathrm{C}_{\mathrm{T}}$ results furnished by us to SIO and reproduced in Guenther et al. (1994). Table 4 of this report therefore supersedes Tables $3 \mathrm{e}$ and 5e of Guenther et al. (1994), and should be referenced for the M18 (A1 / E) $C_{T}$ data in all future work. Six of the seven differences were within the analytical precision of the methods, and salinities agreed to within 0.005 ruling out evaporative losses giving additional weight to these data and the data set as a whole. Figure 3 is a color section plot of the WOCE-WHP A1 / E section.

Alkalinity $\left(\mathrm{A}_{\mathrm{T}}\right)$ samples were collected in $500 \mathrm{~mL}$ bottles with the same precautions as for total carbon dioxide. They were stored in the dark at $4^{\circ} \mathrm{C}$ and analyzed within 24 hours. They were transferred into a closed titration cell with a volume of approximately $120 \mathrm{~mL}$ and titrated at $25 \pm$ $0.1{ }^{\circ} \mathrm{C}$ with $0.1 \mathrm{M} \mathrm{HCl}$ containing $0.6 \mathrm{M} \mathrm{NaCl}$. The titration cell was based on the systems described by Bradshaw and Brewer (1988) and Millero et al. (1993). The potential was followed with an electrode pair consisting of a ROSS (Orion Inc.) glass pH electrode and a ROSS AgCl 
reference electrode connected to a high precision digital voltmeter. The titration was controlled by a computer which waited for stable emf-readings before adding the next acid increment. The titration curve was analyzed with a modified GRAN-plot method described by Stoll et al. (1993) using the cartonic acid constants of Goyet and Poisson (1989) and taking into account the silicate and phosphate concentrations of the sample to obtain the titration alkalinity. The precision of the method was $\pm 2.0 \mu \mathrm{mol} / \mathrm{kg}$ determined by replicate analysis of samples. Standardization was accomplished with $\mathrm{NaCO}_{3}$ standards in $\mathrm{NaCl}$ solutions corrected for the blank arising from impurities in the salt.

Underway $\mathrm{pCO}_{2}$ was measured by the method of Schneider et al. (1992). Surface seawater was continuously pumped at a rate of $200-300 \mathrm{~mL} / \mathrm{min}$ into a glass equilibrator with a volume of approximately $300 \mathrm{~mL}$. The seawater was equilibrated with continuously circulating air entering the bottom of the equilibrator through a frit from a closed loop system. The latter included a heat exchanger to keep the air at the sample temperature, a filter and water trap, and an infra-red (IR) analyzer (Siemens, Ultrmat $5 \mathrm{~F}$ ) for the determination of the $\mathrm{CO}_{2}$ content of the equilibrated air. The IR and the equilibrator temperature sensor were connected to a PC or to an analog recorder for data display and preservation. The time constant for the equilibration was about 3 minutes which corresponded to a spatial resolution of one half a mile with the ship steaming at 10 knots.

Atmospheric air was periodically measured, and the system was calibrated every 12 hours using calibration gases with $\mathrm{CO}_{2}$ mixing ratios of 252.5 and $412.8 \mathrm{ppm}$ (v). Pressure corrections were made for the effect of water vapor on total pressure in the equilibrator and the pressure at the inlet of the IR analyzer, while the correction for the difference between in situ and measuring temperature was made according to Gordon and Jones (1973). 
Accessing the Data Files

Alex ....... 


\section{REFERENCES}

Armstrong, F. A. J., Stearns, C. R., and Strickland, J. D. H. 1967. The measurement of upwelling and subsequent biological processes by means of the Technicon Autoanalyzer and associated equipment. Deep-Sea Res., 14: 381 - 389.

Atlas, E. L., Hager, S. W., Gordon, L. I., and Park, P. K. 1971. A Practical Manual for Use of the Technicon Autoanalyzer in Seawater Nutrient Analyses: Revised Technical Report 215, Reference 71 - 22. Oregon State University, Department of Oceanography. 49 pp.

Bemhardt, H. and Wilhelms, A. 1967. The continuous determination of low level iron, soluble phosphate and total phosphate with the AutoAnalyzer (R). Technicon Symposia, Volume I, 385 - 389.

Bradshaw A. L. and Brewer, P. G. 1988 . High precision measurements of alkalinity and total carbon dioxide in seawater by potentiometric titration-1. Presence of unknown protolyte (s) ? Mar. Chem., 23: 69 - 86.

Brewer, P. G., Goyet, C. , and Dyrssen, D. 1989. Carbon dioxide transport by ocean currents at $25^{\circ} \mathrm{N}$ latitude in the Atlantic Ocean. Science, 246: 477 - 479.

Bryden, H. L. and Hall, M. M. 1980 . Heat transport by ocean currents across $25^{\circ} \mathrm{N}$ latitude in the North Atlantic Ocean. Science, 207: 884.

Carpenter, J. H. 1965. The Chesaspeake Bay Institute technique for the Winkler dissolved oxygen method. Limnol. Oceanogr., 10: 141 - 143.

Culberson, C. H., Williams, R. T., et al. 1991. A comparison of methods for the determination of dissolved oxygen in seawater. WHP Office Report, WHPO 91-2, 15 pp.

DOE Handbook of methods for the analysis of the various parameters of the carbon dioxide system in sea water, version 2.0. 1994. A. G. Dickson and C. Goyet (eds.). Available from Andrew G. Dickson, Marine Physical Laboratory, 0902, University of Califomia San Diego, 9500 Gilman Drive, La Jolla, CA 92093-0902.

Gordon, L. I. and Jones, L. B. 1973. The effect of temperature on carbon dioxide partial pressure in seawater. Mar. Chem., 1: 317 - 322. 
Goyet, C. and Poisson, A. 1989. New determination of carbonic acid dissociation constants in seawater as a function of temperature and salinity. Deep-Sea Res., 36: 1635 - 1654.

Guenther, P. R., Keeling, C. D., and Emanuele, G. 1994. Oceanic $\mathrm{CO}_{2}$ measurements for the WOCE hydrogaphic survey in the Pacific Ocean, 1990 - 1991: Shore based analyses. SIO Reference Series, No. 94 - 28.

Hager, S. W., Atlas, E. L., Gordon, L. D., Mantyla, A. W., and Park, P. K. 1972. A comparison at sea of manual and autoanalyzer analyses of phosphate, nitrate, and silicate. Linmnol. Oceanogr., 17: 931 - 937.

Johnson, K. M., King, A. E., and Sieburth, J. McN. 1985. Coulometric $\mathrm{TCO}_{2}$ analyses for marine studies: An introduction. Mar. Chem., 16:61 - 82.

Johnson, K. M., Sieburth, J. McN, Williams, P. J. leB., Brändstrōm, L. 1987. Coulometric $\mathrm{TCO}_{2}$ analysis for marine studies: Automation and calibration. Mar. Chem., 21: 117133.

Johnson, K. M. and Wallace, D. W. R. 1992. The single-operator multiparameter metabolic analyzer for total carbon dioxide with coulometric detection. DOE Research Summary No. 19. Carbon Dioxide Information Analysis Center, Oak Ridge National Laboratory, TN.

Johnson, K. M., Wills, K. D., Butler, D. B., Johnson, W. K., Wong, C. S. 1993. Coulometric total carbon dioxide analysis for marine studies: maximizing the performance of an automated gas extraction system and coulometric detector. Mar. Chem., 44: 167 - 187.

Johnson, K. M., Wallace, D. W. R., Wilke, R., and Goyet, C. 1995. Carbon dioxide, Hydrographic, and chemical data from the F/ S Meteor Cruise 15/3 in the South Atlantic Ocean (WOCE Section A-9) during February - March 1991. Carbon Dioxide Information Analysis Center (CDIAC), Oak Ridge National Laboratory, Oak Ridge, TN. Submitted.

Meincke, J. (ed.). 1993. WOCE-NORD 1991, Cruise No. 18, 2 September - 26 September 1991, METEOR - Berichte No. 93-1, Institut für Meereskunde der Universităt Hamburg, $44 \mathrm{pp}$.

Millard, R. C. 1991. CTD oxygen calibration procedure. WHP Operations and Methods, WHP Office Report, WHPO 91 - 1, 27 pp.

Millero, F. J. and Poisson, A. 1981. International one-atmosphere equation of state for sea water. 
Deep-Sea Res., 28: 625 - 629.

Millero, F. J., Zhang, J.-Z., Lee, K., and Campbell, D. M. 1993. Titration alkalinity of seawater. Mar. Chem., 44: 153 - 165.

Roemmich, D. and Wunsch, C. 1985. Two transatlantic sections: meridional circulation and heat flux in the subtropical North Atlantic Ocean. deep Sea Res., 32: 619 - 664.

Schneider, B., Kremling, K., and Duinker, J. C. $1992 . \mathrm{CO}_{2}$ partial pressure in northeast Atlantic and adjacent shelf waters: Processes and seasonal variability. J. Mar. Systems, 3:453 463.

Siedler, G., Zenk, W. 1992. WOCE Sudatlantik 1991, Reise Nr. 15, 30 Dezember 1990 - 23 Marz 1991. METEOR-Berichte, Universität Hamburg, 92 - 1, 126 pp.

Stoll, M. H. C., Rommets, J. W., and De Baar, H. J. W. 1993. Effect of selected calculation routines and dissociation constants on the determination of total carbon dioxide in seawater. Deep-Sea Res., 40: 1307 - 1322.

WHP One-Time Section A9 Data Report (C M. Ruhsam, prep.). 1994. WOCE Report A9, WOCE Special Analysis Center, Bundesamt fuer Seeshiffahrt and Hydrographie, Hamburg. Unpublished Manuscript.

Wilke, R. J., Wallace, D. W. R., and Johnson, K. M. 1993. A water-based, gravimetric method for the determination of gas sample loop volume. Anal. Chem., 65: 2403 - 2406.

Youden, W. J. 1951. Statistical Methods for Chemists. Wiley, New York, 126 pp. 


\section{FIGURE CAPTIONS}

Figure 1. Station locations along the A1 / E WOCE Section during the Meteor 18 Cruise. (Alex you may want to distinguish between regular stations and $\mathrm{CO}_{2}$ stations ?)

Figure 2. The distribution of the recording current meter moorings $\mathrm{A}$ to $\mathrm{F}$ along the section $\mathrm{A} 1$ / $\mathrm{E}$ overlaid on the observed temperature distributions. The current meter depths are indicated by a dot.

Figure 3. Color contour section plot of the $\mathrm{C}_{\mathrm{T}}$ data obtained during the $\mathrm{Al} / \mathrm{E}$ transect in September 1991.. 